\title{
Novel sesquiterpenes and norergosterol from the soft corals Nephthea erecta and Nephthea chabroli
}

\author{
Shi-Yie Cheng ${ }^{a}$, Ya-Chiang Huang ${ }^{a}$, Zhi-Hong Wen ${ }^{a}$, Shu-Fen Chiou ${ }^{a}$, Shang-Kewi Wang ${ }^{b}$ \\ Chi-Hsin Hsu ${ }^{\mathrm{a}}$, Chang-Feng Dai ${ }^{\mathrm{c}}$, Chang-Yih Duh ${ }^{\mathrm{a}, \mathrm{d}, *}$ \\ a Department of Marine Biotechnology and Resources, National Sun Yat-Sen University, Kaohsiung 804, Taiwan \\ ${ }^{\mathrm{b}}$ Department of Microbiology, Kaohsiung Medical University, Kaohsiung 807, Taiwan \\ ${ }^{\mathrm{c}}$ Institute of Oceanography, National Taiwan University, Taipei, Taiwan \\ ${ }^{\mathrm{d}}$ Center of Asia-Pacific Marine Researches, National Sun Yat-sen University, Kaohsiung, Taiwan
}

\section{A R T I C L E I N F O}

\section{Article history:}

Received 1 November 2008

Revised 27 November 2008

Accepted 1 December 2008

Available online 6 December 2008

\section{Keywords:}

Nephthea erecta

Calamenene-type

Mercaptan

sec-Germacrane

Norergosterol

Nephthea chabroli

Anti-inflammatory activity

Antimicrobial activities

\begin{abstract}
A B S T R A C T
Chemical investigations on the acetone extract of the Formosan soft coral Nephthea erecta have afforded a new calamenene-type sesquiterpene with a mercaptan group at C-15, erectathiol (1), and a previously reported sesquiterpenoid, (+)-trans-calamenene (2). A novel sec-germacrane sesquiterpene (3), along with a novel norergosterol, chabrosterol (4), possessing a 19-norergostane skeleton, was isolated from the other soft coral Nephthea chabroli. The structures of these metabolites were elucidated through extensive spectroscopic analyses. In vitro anti-inflammatory activity of $\mathbf{1}$ and $\mathbf{4}(10 \mu \mathrm{M})$ significantly reduced the levels of the iNOS protein $(58.0 \pm 6.5 \%$ and $12.4 \pm 2.9 \%)$ and COX-2 protein $(108.7 \pm 4.5 \%$ and $45.2 \pm 5.4 \%)$. In addition, metabolite $1(166 \mu \mathrm{g} /$ disk $)$ exhibited antimicrobial activities against a small panel of bacterial strains.
\end{abstract}

(c) 2008 Elsevier Ltd. All rights reserved.
The family Nephtheidae has been proved to be a rich source of bioactive sesquiterpenoids and steroids. ${ }^{1-10}$ Recently, many savants have paid much attention to these secondary metabolites due to their biological activities. A number of sesquiterpenoids have shown an array of biological activities such as insecticidal ${ }^{2}$ and cytotoxic activities. ${ }^{3,4}$ Some of steroids were reported to possess cytotoxic ${ }^{5-8}$ and anti-inflammatory activities. ${ }^{9}$ In the course of our ongoing endeavor to discover bioactive secondary metabolites from marine organisms, chemical investigations of the Formosan soft corals Nephthea erecta Kükenthal and Nephthea chabroli Audouin were undertaken. ${ }^{4,6,7}$

Chromatographic separation on the acetone extract of the soft coral $N$. erecta led to the isolation of a new calamenene-type sesquiterpene, erectathiol (1), together with a known calamenenetype sesquiterpene, (+)-trans-calamenene (2) (Fig. 1), which was also isolated from the soft coral Sarcophyton glaucum ${ }^{11 a}$ and the liverwort Conocephalum conicum. ${ }^{11 \mathrm{~b}}$ We have obtained a novel sec-germacrane sesquiterpene, (2E,6E)-3-isopropyl-6-methyl-10oxoundeca-2,6-dienal (3), and a novel 19-norergosterol, chabrosterol (4) (Fig. 1), from the other soft coral $N$. chabroli. To the best

\footnotetext{
* Corresponding author. Tel.: +886 7 5252000x5036; fax: +886 75255020

E-mail address: yihduh@mail.nsysu.edu.tw (C.-Y. Duh).
}

of our knowledge, erectathiol (1) (possessing a rare mercaptan moiety at C-15), (2E,6E)-3-isopropyl-6-methyl-10-oxoundeca-2,6dienal (3) (a novel sec-germacrane skeleton), and chabrosterol (4) (a novel 19-norergostane skeleton) are reported from marine soft corals for the first time. The details of isolation and structural elucidation of these isolated metabolites are discussed in this Letter. The in vitro anti-inflammatory activities of $\mathbf{1}$ and $\mathbf{4}$ were measured, and the antibacterial activities against Enterobacter aerogenes (ATCC13048), Serratia marcescens (ATCC25419), Salmonella enteritidis (ATCC13076), Yersinia enterocolitica (ATCC23715), and Shigella sonnei (ATCC11060) of $\mathbf{1}$ were also evaluated in vitro. Meanwhile, the plausible biosynthetic pathways for formation of these isolated metabolites were postulated, see below.

The soft corals $N$. erecta and $N$. chabroli were collected by hand using scuba at the Green Island and Siaoliouciou Island off Taiwan, respectively. Both specimens were identified by Prof. C.-F. Dai, and voucher specimens were deposited in the Department of Marine Biotechnology and Resources, National Sun Yat-sen University.

The acetone extract of $N$. erecta was concentrated to a brown gum, which was partitioned with EtOAc and $\mathrm{H}_{2} \mathrm{O}$. The EtOAc-soluble residue $(35.0 \mathrm{~g})$ was subjected to CC on silica gel using $n$-hexane-EtOAc mixtures of increasing polarity for elution, to fractionate 40 fractions. Fraction $2(6.0 \mathrm{~g})$ was subjected to CC on 


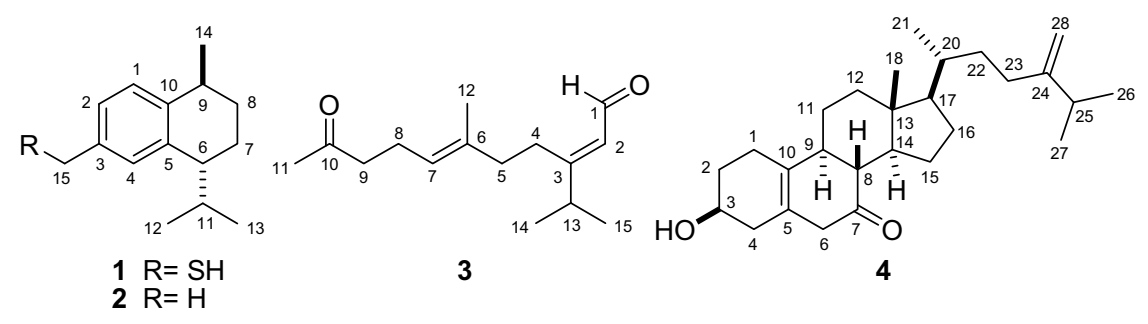

Figure 1. Structures of metabolites 1-4.

silica gel to obtain $2(1.0 \mathrm{mg})$. Similarly, metabolite $\mathbf{1}(4.0 \mathrm{mg})$ was purified by NP-HPLC using $n$-hexane- $\mathrm{CH}_{2} \mathrm{Cl}_{2}$ (90:1). In the same manner, the EtOAc fraction (100.0 g) of the other soft coral N. chabroli was subjected to CC on silica gel to furnish 40 fractions. Duplicate samples $(2.0 \mathrm{~g})$ of fraction $10(7.5 \mathrm{~g})$ was fractionated over a $\mathrm{PR}-18$ gel column using $\mathrm{MeOH}-\mathrm{H}_{2} \mathrm{O}$ mixtures of increasing polarity for elution, to separate six subfractions. Subfraction 2 (26 mg) was subjected to a PR-18 gel column to obtain a mixture (12 mg) that was further purified by RP-HPLC using $75 \% \mathrm{MeOH}$ in $\mathrm{H}_{2} \mathrm{O}$ to yield 3 (2 mg). Fraction 12 (4.0 g) was fractionated over Sephadex LH$20(100 \%$ acetone) to produce 40 subfractions. Subfraction 36 (102 mg) was subjected to CC on silica gel to obtain a mixture (64 mg) that was further purified by RP-HPLC using 95\% MeOH in $\mathrm{H}_{2} \mathrm{O}$ to give 4 (2 $\left.\mathrm{mg}\right)$.

Erectathiol $(\mathbf{1})^{12}$ was obtained as a light yellow oil. The molecular formula was determined to be $\mathrm{C}_{15} \mathrm{H}_{22} \mathrm{~S}$, as deduced from HRFABMS $\left(\mathrm{m} / \mathrm{z} 235.1521,[\mathrm{M}+\mathrm{H}]^{+}\right)$and ${ }^{13} \mathrm{C}$ NMR spectroscopic data (Table 1$)$, implying the existence of five degrees of unsaturation. The NMR spectrum (Table 1 ) showed a trisubstituted phenyl moiety $\left[{ }^{1} \mathrm{H}\right.$ NMR $\delta_{\mathrm{H}} 7.16,7.01(d, J=8.0 \mathrm{~Hz}, 1 \mathrm{H}$ each), and 7.07 (br s, $1 \mathrm{H}) ;{ }^{13} \mathrm{C}$ NMR $\delta_{\mathrm{C}} 127.0,126.1,135.7,128.7,140.2$, and 142.1]. The above functionalities also account for four of the five degrees of unsaturation, suggesting a bicyclic structure in 1. Moreover, the ${ }^{13} \mathrm{C}$ NMR and DEPT spectra revealed 15 carbon signals, including three methyls, three methylenes, six methines, and three quaternary carbons. The above data of 1 were similar to those of (-)-trans-calamenene, ${ }^{11 \mathrm{~b}}$ except for the replacement of the methyl by a mercaptan group $\left[\delta_{\mathrm{H}} 3.89\right.$, $3.81\left(\mathrm{~d}, J=10.8 \mathrm{~Hz}, 1 \mathrm{H}\right.$ each) and $\left.\delta_{\mathrm{C}} 32.9(\mathrm{t})\right]$ at $\mathrm{C}-15 .{ }^{13}$ This was supported by $\mathrm{HMBC}$ spectrum that long-range ${ }^{1} \mathrm{H}-{ }^{13} \mathrm{C}$ correlations were observed from $\mathrm{H}-15$ to $\mathrm{C}-2, \mathrm{C}-3$, and C-4. Thus, the planar structure of 1 was established unambiguously.

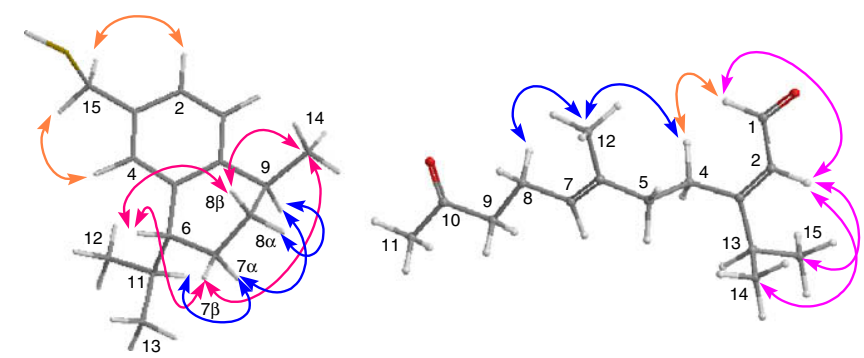

Figure 2. Key NOE correlations and computer-generated perspective model using MM2 force field calculations for $\mathbf{1}$ and $\mathbf{3}$.

The NOE correlations (Fig. 2) between H-7 $\beta$ with the following protons of $\mathrm{H}-6$ and Me-14, and Me- 14 and $\mathrm{H}-8 \beta$ suggested that these protons were oriented on the same side of the cyclohexene moiety, while the isopropyl group at C-6 was oriented on the opposite side. Moreover, the absolute stereochemistry of 1 was further elucidated by comparison of its optical rotation, $[\alpha]_{\mathrm{D}}^{24}+23\left(c 0.4, \mathrm{CHCl}_{3}\right)$, with that of (-)-trans-calamenene. ${ }^{11 \mathrm{~b}}$ From the above-mentioned findings, metabolite 1 was formulated as [(6R,9S)-6-isopropyl-9methyl-6,7,8,9-tetrahydronaphthalen-3-yl]methanethiol.

Metabolite $3^{14}$ analyzed for a molecular formula of $\mathrm{C}_{15} \mathrm{H}_{24} \mathrm{O}_{2}$, according to the interpretation of its HRESIMS and NMR spectroscopic data (Table 1), implies four degrees of unsaturation. The IR absorptions of 3 at 2874 and $1671 \mathrm{~cm}^{-1}$ revealed the presence of a conjugated aldehyde functionality. This was further indicated from the ${ }^{1} \mathrm{H}$ NMR signals at $\delta 9.93(1 \mathrm{H}, \mathrm{d}, J=8.0 \mathrm{~Hz})$ and 5.78 $(1 \mathrm{H}, \mathrm{d}, J=8.0 \mathrm{~Hz})$, and ${ }^{13} \mathrm{C}$ NMR signals at $\delta 189.5(\mathrm{CH}, \mathrm{C}-1)$, $124.1(\mathrm{CH}, \mathrm{C}-2)$, and 170.2 (qC, C-3). The UV absorption maxima

Table 1

${ }^{1} \mathrm{H}$ and ${ }^{13} \mathrm{C}$ NMR spectroscopic data of metabolites $\mathbf{1}$ and $\mathbf{3}^{\mathrm{a}}$

\begin{tabular}{|c|c|c|c|c|c|c|c|c|}
\hline \multirow[t]{2}{*}{$\mathrm{C} / \mathrm{H}$} & \multicolumn{4}{|c|}{1} & \multicolumn{4}{|c|}{3} \\
\hline & ${ }^{13} \mathrm{C}$ & ${ }^{1} \mathrm{H}$ & COSY & HMBC & ${ }^{13} \mathrm{C}$ & ${ }^{1} \mathrm{H}$ & COSY & HMBC \\
\hline 1 & $127.0(d)^{b}$ & $7.16 \mathrm{~d}(8.0)^{\mathrm{c}}$ & 2 & 3,5 & $189.5(d)^{b}$ & $9.93 d(8.0)^{c}$ & 2 & 2 \\
\hline 2 & $126.1(d)$ & $7.01 \mathrm{~d}(8.0)$ & 1 & 4,10 & $124.1(d)$ & $5.78 \mathrm{~d}(8.0)$ & 1 & 4,13 \\
\hline 3 & $135.7(\mathrm{~s})$ & & & & $170.2(\mathrm{~s})$ & & & \\
\hline 4 & $128.7(d)$ & $7.07 \mathrm{~s}$ & & 2,10 & $30.5(\mathrm{t})$ & $2.63 \mathrm{t}(8.0)$ & 5 & $2,3,5,6,13$ \\
\hline 5 & $140.2(\mathrm{~s})$ & & & & $41.0(t)$ & $2.17 \mathrm{t}(8.0)$ & 4 & 6,7 \\
\hline 6 & $43.8(d)$ & $2.71 \mathrm{~m}$ & 7,11 & & $133.6(\mathrm{~s})$ & & & \\
\hline 7 & $21.4(\mathrm{t})$ & $\alpha: 1.61 \mathrm{~m} ; \beta: 1.83 \mathrm{~m}$ & 6,8 & & $123.6(d)$ & $5.11 \mathrm{t}(6.4)$ & 8 & 5,8 \\
\hline 8 & $30.6(t)$ & $\alpha: 1.95 \mathrm{~m} ; \beta: 1.36 \mathrm{~m}$ & 7,9 & & $23.3(\mathrm{t})$ & 2.26 dd $(7.6,6.4)$ & 7,9 & $6,7,10$ \\
\hline 9 & $32.7(d)$ & $2.75 \mathrm{~m}$ & 8,14 & & $44.0(\mathrm{t})$ & $2.46 \mathrm{t}(7.6)$ & 8 & 7,10 \\
\hline 10 & $142.1(\mathrm{~s})$ & & & & $206.1(\mathrm{~s})$ & & & \\
\hline 11 & 31.9 (d) & $2.23 \mathrm{~m}$ & $6,12,13$ & & $30.8(q)$ & $2.14 \mathrm{~s}$ & & 9,10 \\
\hline 12 & $17.4(\mathrm{q})$ & $0.71 \mathrm{~d}(6.8)$ & 11 & $6,11,13$ & $17.2(\mathrm{q})$ & 1.66 br s & & $5,6,7$ \\
\hline 13 & $21.3(\mathrm{q})$ & $1.01 \mathrm{~d}(6.8)$ & 11 & $6,11,13$ & 36.5 (d) & 2.41 septet $(6.8)$ & & 3 \\
\hline 14 & $22.3(\mathrm{q})$ & $1.26 \mathrm{~d}(6.8)$ & 9 & $8,9,10$ & $22.4(\mathrm{q})$ & $1.11 \mathrm{~d}(6.8)$ & & $3,13,15$ \\
\hline \multirow[t]{2}{*}{15} & $32.9(\mathrm{t})$ & $\alpha: 3.89 \mathrm{~d}(10.8)$ & & & & & & \\
\hline & & $\beta: 3.81 \mathrm{~d}(10.8)$ & & $2,3,4$ & $22.4(\mathrm{q})$ & $1.11 \mathrm{~d}(6.8)$ & & $3,13,14$ \\
\hline
\end{tabular}

\footnotetext{
a Spectra were measured in $\mathrm{CDCl}_{3}\left({ }^{1} \mathrm{H}, 400 \mathrm{MHz}\right.$ and $\left.{ }^{13} \mathrm{C}, 100 \mathrm{MHz}\right)$.

b Multiplicities are deduced by HSQC and DEPT experiments.

c $J$ values (in $\mathrm{Hz}$ ) are in parentheses.
} 
Table 2

${ }^{1} \mathrm{H}$ and ${ }^{13} \mathrm{C}$ NMR spectroscopic data of chabrosterol (4)

\begin{tabular}{|c|c|c|c|c|}
\hline \multirow[t]{2}{*}{$\mathrm{C} / \mathrm{H}$} & \multicolumn{4}{|c|}{4} \\
\hline & ${ }^{13} \mathrm{C}$ & ${ }^{1} \mathrm{H}$ & COSY & HMBC \\
\hline 1 & $24.4(\mathrm{t})^{\mathrm{b}}$ & $\alpha: 2.15 \mathrm{~m} ; \beta: 2.59 \mathrm{~m}$ & 2 & \\
\hline 2 & $28.8(\mathrm{t})$ & $\alpha: 1.69 \mathrm{~m} ; \beta: 1.80 \mathrm{~m}$ & 1,3 & \\
\hline 3 & $65.0(d)$ & $4.13 \mathrm{~m}$ & 2,4 & \\
\hline 4 & $31.3(\mathrm{t})$ & $\alpha: 2.52 \mathrm{~m} ; \beta: 2.27 \mathrm{~m}$ & 3 & 5 \\
\hline 5 & $158.6(\mathrm{~s})$ & & & \\
\hline 6 & $43.2(\mathrm{t})$ & $\alpha: 2.01 \mathrm{~d}(16.5)^{\mathrm{c}} ; \beta: 2.49 \mathrm{dd}(16.5,3.5)$ & & $5,7,8,10$ \\
\hline 7 & $199.1(\mathrm{~s})$ & & & \\
\hline 8 & $39.4(d)$ & $1.82 \mathrm{~m}$ & 9,14 & \\
\hline 9 & $46.2(d)$ & $2.00 \mathrm{~m}$ & 8,11 & $5,7,8$ \\
\hline 10 & $128.8(\mathrm{~s})$ & & & \\
\hline 11 & $24.5(t)$ & $\alpha: 1.95 \mathrm{~m} ; \beta: 1.43 \mathrm{~m}$ & 9,12 & \\
\hline 12 & $39.8(\mathrm{t})$ & $\alpha: 1.29 \mathrm{~m} ; \beta: 2.09 \mathrm{~m}$ & 11 & \\
\hline 13 & $42.5(\mathrm{~s})$ & & & \\
\hline 14 & $55.0(\mathrm{~d})$ & $1.29 \mathrm{~m}$ & 8,15 & \\
\hline 15 & $23.4(\mathrm{t})$ & $\alpha: 1.58 \mathrm{~m} ; \beta: 1.09 \mathrm{~m}$ & 14,16 & \\
\hline 16 & $28.1(t)$ & $\alpha: 1.89 \mathrm{~m} ; \beta: 1.29 \mathrm{~m}$ & 15,17 & \\
\hline 17 & 55.9 (d) & $1.19 \mathrm{~m}$ & 16,20 & \\
\hline 18 & $12.0(q)$ & $0.71 \mathrm{~s}$ & & $12,13,14,17$ \\
\hline 20 & $35.6(d)$ & $1.43 \mathrm{~m}$ & $17,21,22$ & \\
\hline 21 & $18.6(q)$ & $0.96 \mathrm{~d}(6.5)$ & 20 & $17,20,22$ \\
\hline 22 & $34.6(t)$ & $\alpha: 1.16 \mathrm{~m} ; \mathrm{b}: 1.53 \mathrm{~m}$ & 20,23 & \\
\hline 23 & $30.9(t)$ & $\alpha: 1.88 \mathrm{~m} ; \mathrm{b}: 2.09 \mathrm{~m}$ & 22 & 24 \\
\hline 24 & $156.7(\mathrm{~s})$ & & & \\
\hline 25 & 33.8 (d) & 2.23 septet (6.5) & 26,27 & \\
\hline 26 & $21.8(\mathrm{q})$ & $1.03 \mathrm{~d}(6.5)$ & 25 & $24,25,27$ \\
\hline 27 & $22.0(\mathrm{q})$ & $1.03 \mathrm{~d}(6.5)$ & 25 & $24,25,26$ \\
\hline 28 & $106.0(\mathrm{t})$ & $\alpha: 4.66 \mathrm{~s} ; \mathrm{b}: 4.72 \mathrm{~s}$ & & 23,25 \\
\hline
\end{tabular}

a Spectra were measured in $\mathrm{CDCl}_{3}\left({ }^{1} \mathrm{H}, 500 \mathrm{MHz}\right.$ and $\left.{ }^{13} \mathrm{C}, 125 \mathrm{MHz}\right)$.

b Multiplicities are deduced by HSQC and DEPT experiments.

c $J$ values (in $\mathrm{Hz}$ ) are in parentheses.

$241 \mathrm{~nm}$ suggested the aforementioned chromophore. A keto-carbonyl group was recognized as being present in 3 from its ${ }^{13} \mathrm{C}$ NMR signal at $\delta 206.1$ (qC, C-10), as well as from a broad IR absorption at $1716 \mathrm{~cm}^{-1}$. Moreover, the ${ }^{1} \mathrm{H}$ and ${ }^{13} \mathrm{C}$ NMR spectroscopic data of 3 contained resonances for a trisubstituted double bond at C-6 and C-7 [ $\delta_{\mathrm{H}} 5.11(\mathrm{t}, J=6.4 \mathrm{~Hz}, 1 \mathrm{H}) ; \delta_{\mathrm{C}} 133.6(\mathrm{qC})$ and 123.6 $(\mathrm{CH})]$. The above functionalities accounted for four of the four degrees of unsaturation, suggesting a linear structure for $\mathbf{3}$.

By interpretation of ${ }^{1} \mathrm{H}-{ }^{1} \mathrm{H}$ COSY correlations, it was possible to establish four partial structures of consecutive proton systems extending from $\mathrm{H}-1$ to $\mathrm{H}-2$, from $\mathrm{H}_{2}-4$ to $\mathrm{H}_{2}-5$, from $\mathrm{H}_{3}-14$ to $\mathrm{H}_{3}-$ 15 through $\mathrm{H}-13$, and from $\mathrm{H}_{2}-9$ to $\mathrm{H}_{3}-12$ through $\mathrm{H}-7$ and $\mathrm{H}_{2}-8$, as well as long-range COSY correlation between $\mathrm{H}_{3}-12$ and $\mathrm{H}-7$. Moreover, the connectivities of these partial structures were further established by the HMBC correlations. On the basis of the above observations, the sec-germacrane structure of $\mathbf{3}$ was established unambiguously. The geometry of the trisubstituted olefins was assigned as $E$ based on the $\gamma$-effect of the olefinic methyl signal for C-12 (less than $20 \mathrm{ppm}$ ) and the NOESY correlation between $\mathrm{H}_{2}-8$ and $\mathrm{H}_{3}-12$. The NOE correlations (Fig. 2) between $\mathrm{H}-1 / \mathrm{H}_{2}-4$, $\mathrm{H}-2 / \mathrm{H}_{3}-14$, and $\mathrm{H}-2 / \mathrm{H}_{3}-15$ indicated the $s$-trans geometry of the conjugated aldehyde moiety. All the NMR spectroscopic data of metabolite 3, assigned by COSY, HMQC, HMBC, and NOESY correlations, were satisfactorily consistent with the structure shown as (2E,6E)-3-isopropyl-6-methyl-10-oxoundeca-2,6-dienal.

Chabrosterol $(\mathbf{4})^{15}$ was isolated as a white amorphous powder. HRESIMS of 4 exhibited a pseudo molecular ion peak at $\mathrm{m} / \mathrm{z}$

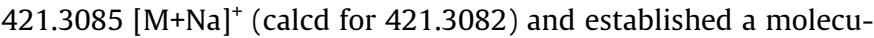
lar formula of $\mathrm{C}_{27} \mathrm{H}_{42} \mathrm{O}_{2}$, indicating seven degrees of unsaturation. The ${ }^{13} \mathrm{C}$ NMR displayed 27 carbon signals, which were identified by the assistance of the DEPT spectrum as four methyls, eleven methylenes, seven methines, and five quaternary carbons. The ${ }^{1} \mathrm{H}$ NMR signal $\left[\delta_{\mathrm{H}} 4.13(\mathrm{~m}, 1 \mathrm{H})\right]$ (Table 2) and IR absorption at $3309 \mathrm{~cm}^{-1}$, together with the observation of one oxygen-bearing carbon resonance $\left(\delta_{\mathrm{C}} 65.0\right)$ in ${ }^{13} \mathrm{C}$ NMR spectrum (Table 2$)$, revealed the presence of one hydroxyl. Furthermore, one tetrasubstituted double bond ( $\delta_{\mathrm{C}} 128.8$ and 158.6), one terminal double bond $\left(\delta_{\mathrm{C}}\right.$ 106.0 and 156.7), and one carbonyl carbon $\left(\delta_{\mathrm{C}} 199.1\right)$ were assigned from ${ }^{13} \mathrm{C}$ NMR and DEPT spectra of 4 . The above functionalities accounted for three of the seven degrees of unsaturation, suggesting a tetracyclic skeleton for 4 .

Interpretation of the ${ }^{1} \mathrm{H}-{ }^{1} \mathrm{H}$ COSY spectrum led to three partial structures. The connectivities of these partial structures were further established by the HMBC correlations. Moreover, the longrange ${ }^{1} \mathrm{H}-{ }^{13} \mathrm{C}$ correlations observed from $\mathrm{H}_{2}-6$ to $\mathrm{C}-7$, and $\mathrm{H}-9$ to C-7 indicated the position of the carbonyl group at C-7. The COSY correlations from $\mathrm{H}_{2}-1$ to $\mathrm{H}-3$ through $\mathrm{H}_{2}-2$ led the assignment of the one secondary hydroxyl group at $\mathrm{C}-3$. The location of the tetrasubstituted double bond at $\mathrm{C}-5 / \mathrm{C}-10$ was clarified by analysis of the $\mathrm{HMBC}$ correlations from $\mathrm{H}_{2}-4$ to $\mathrm{C}-5$, and $\mathrm{H}_{2}-6$ to $\mathrm{C}-10$, and $\mathrm{H}-9$ to $\mathrm{C}-5$. The NOESY correlations (Fig. 3 ) observed between $\mathrm{H}-3$ and $\mathrm{H}-2 \alpha$ and $\mathrm{H}-4 \alpha$ indicated the $\beta$-oriented of the hydroxyl group at $\mathrm{C}-3$. Moreover, the NOESY correlations observed between $\mathrm{H}-2 \beta$ and $\mathrm{H}-1 \beta, \mathrm{H}-4 \alpha$ and $\mathrm{H}-6 \alpha, \mathrm{H}-6 \beta$ and $\mathrm{H}-8, \mathrm{H}-9$ and $\mathrm{H}-14, \mathrm{H}-11 \beta$ and $\mathrm{H}-12 \beta, \mathrm{H}-12 \beta$ and $\mathrm{Me}-18$, Me-18 and $\mathrm{H}-20$, and Me-21 and

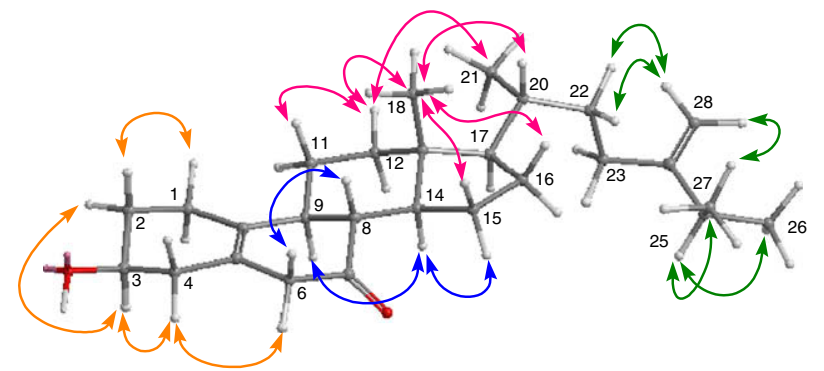

Figure 3. Key NOE correlations and computer-generated perspective model using MM2 force field calculations for 4 . 


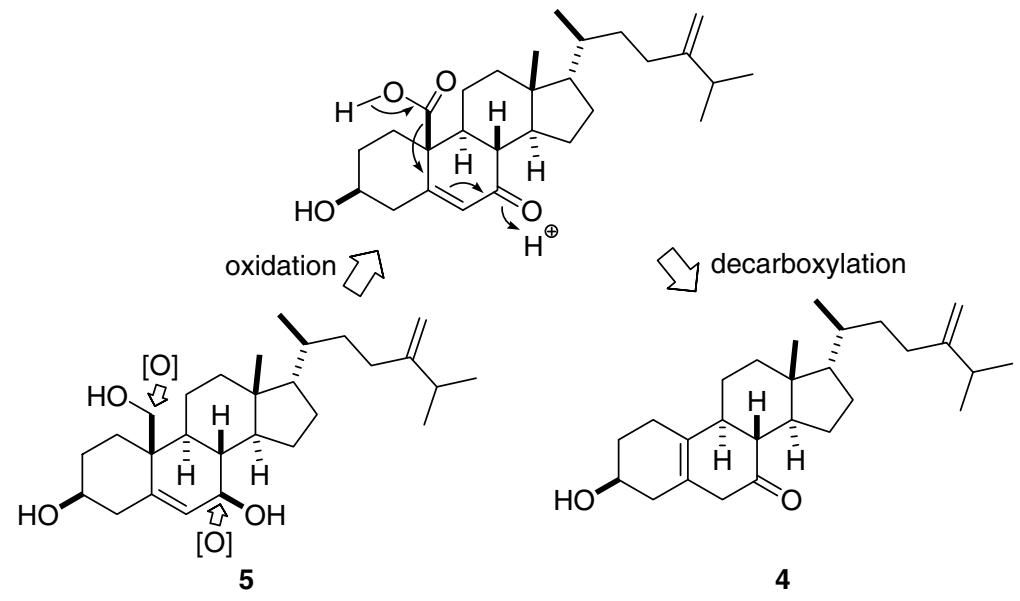

Scheme 1. Plausible biosynthetic pathway for formation of 4 .

A

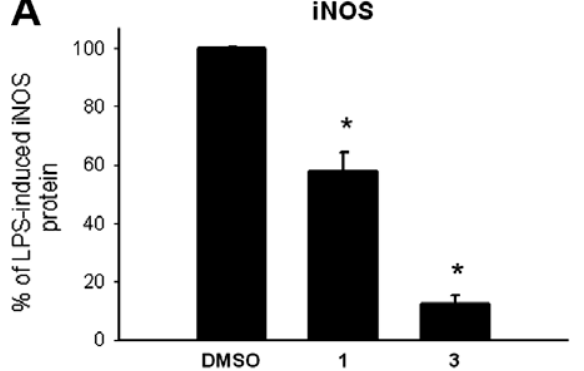

B

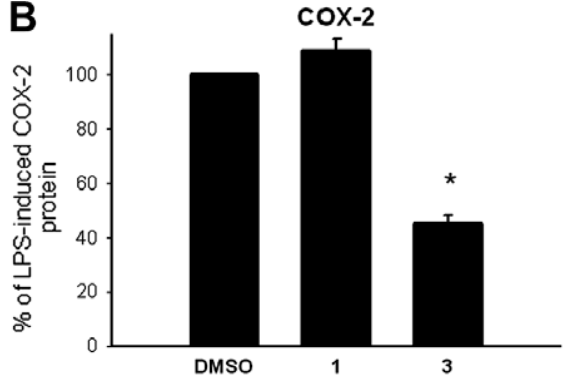

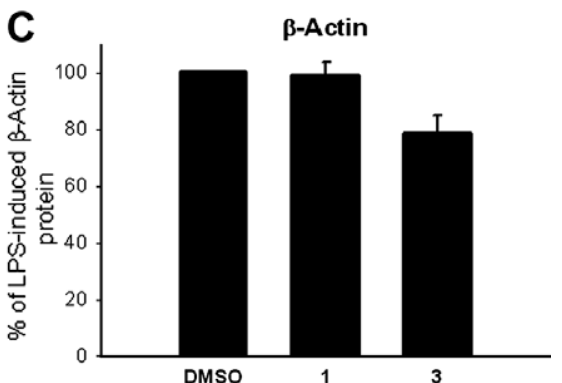

3

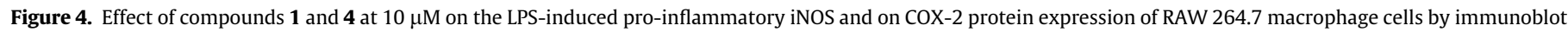

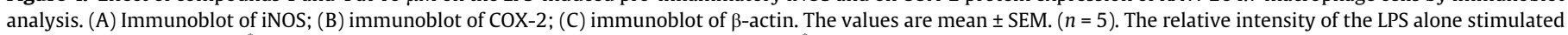
group was taken as $100 \%$. "Significantly different from LPS-stimulated (control) group $\left({ }^{*} P<0.05\right)$.

$\mathrm{H}-12 \beta$ in 4 confirmed the relative configurations for each ring junction and chiral center. Thus, the structure of $\mathbf{4}$ was established unambiguously.

The main novelty of $\mathbf{1}$ is the presence of a calamanene skeleton with a rare mercaptan moiety at C-15. Erectathiol (1), possessing a rare mercaptan moiety, differs from previously calamenene-type sesquiterpenoids isolated from marine soft corals. Biosynthetically, it is suggested that a new approach for exhaustive transformation of 1, in two steps mainly involves benzylic oxidation and acid-induced mercaptanization at $\mathrm{C}-15$ of $\mathbf{1}$. In addition, a plausible oxidation mechanism (dihydroxylation and oxidative cleavage of diols) of formation of metabolite $\mathbf{3}$ was postulated. It is worthwhile to mention that metabolite 4 represents the first 19-norergosterol. Because of biogenic considerations, metabolite 4 may be involved in the biosynthesis of $\mathbf{5}^{16}$ through oxidation and 19-decarboxylation of $\mathbf{4}$ as depicted in Scheme 1.

Preliminary antibacterial activity revealed that metabolite $\mathbf{1}$, at a concentration of $166 \mu \mathrm{g} /$ disk, exhibited moderate activities against four bacterial strains, comprising E. aerogenes, $S$. marcescens, Y. enterocolitica, and S. sonnei. Under the same concentration, metabolite 1 revealed greater antibacterial potential than the positive control (ampicillin) against $S$. enteritidis. The antibacterial assays were carried out according to the procedure described previously. ${ }^{17}$

In vitro anti-inflammatory activity of metabolites $\mathbf{1}$ and $\mathbf{4}$ were tested using LPS-stimulated cells. Stimulation of RAW 264.7 cells with LPS resulted in up-regulation of the pro-inflammatory iNOS and COX-2 proteins. At a concentration of $10 \mu \mathrm{M}$, metabolites 1 and 4 significantly reduced the levels of the iNOS protein $(58.0 \pm 6.5 \%$ and $12.4 \pm 2.9 \%)$ and COX-2 protein $(108.7 \pm 4.5 \%$ and
$45.2 \pm 5.4 \%$ ) compared with the control cells (LPS alone) (Fig. 4). The primary anti-inflammatory results of $\mathbf{1}$ exhibited the observed activity against iNOS protein expression, but no discernible activity against COX-2 protein expression. Besides, chabrosterol (4), possessing a novel 19-norergostane skeleton, showed significantly anti-inflammatory activity against LPS-stimulated RAW 264.7 cells. The anti-inflammatory assay was carried out according to the procedure described previously. ${ }^{17}$

\section{Acknowledgments}

Financial support was provided by the National Science Council (NSC96-2320-B-110-003-MY3) and Ministry of Education (96C031703) of the Republic of China awarded to C.-Y.D.

\section{References and notes}

1. Blunt, J. W.; Copp, B. R.; Hu, W.-P.; Munro, M. H. G.; Northcote, P. T.; Prinsep, M. R. Nat. Prod. Rep. 2008, 25, 35-94. and literature cited in previous review.

2. Handayani, D.; Edrada, R. A.; Proksch, P.; Wray, V.; Witte, L. J. Nat. Prod. 1997, 60, 716-718.

3. Duh, C.-Y.; Wang, S.-K.; Weng, Y.-L.; Chiang, M. Y.; Dai, C.-F. J. Nat. Prod. 1999, 62, 1518-1521.

4. Cheng, S.-Y.; Dai, C.-F.; Duh, C.-Y. J. Nat. Prod. 2007, 70, 1449-1453.

5. El-Gamal, A. A. H.; Wang, S.-K.; Dai, C.-F.; Duh, C.-Y.J. Nat. Prod. 2004, 67, 14551458.

6. Duh, C.-Y.; Wang, S.-K.; Chu, M.-J.; Sheu, J.-H. J. Nat. Prod. 1998, 61, 1022-1024.

7. Cheng, S.-Y.; Dai, C.-F.; Duh, C.-Y. Steroids 2007, 72, 653-659.

8. Shao, Z.-Y.; Zhu, D.-Y.; Guo, Y.-W. J. Nat. Prod. 2002, 65, 1675-1677.

9. Huang, Y.-C.; Wen, Z.-H.; Wang, S.-K.; Hsu, C.-H.; Duh, C.-Y. Steroids 2008, 73, 1181-1186.

10. (a) Ma, K.; Li, W.; Fu, H.; Koike, K.; Lin, W.; van Ofwegen, L.; Fu, H. Steroids 2007, 72, 901-907; (b) Rao, M. R.; Venkateshan, U.; Venkateswarlu, Y. J. Nat. Prod. 1999, 62, 1584-1585. 
11. (a) Feller, M.; Rudi, A.; Berer, N.; Goldberg, I.; Stein, Z.; Benayahu, Y.; Kashman, Y. J. Nat. Prod. 2004, 67, 1303-1308; (b) Melching, St.; Bülow, N.; Wihstutz, K.; Jung, St.; König, W. A. Phytochemistry 1997, 44, 1291-1296.

12. Erectathiol (1): Primrose yellow oil; $[\alpha]_{\mathrm{D}}^{24}+23\left(\right.$ c $\left.0.4, \mathrm{CHCl}_{3}\right)$; IR $(\mathrm{KBr}) v_{\max } 3035$ 2927, 2864, 1633, 1456, $1372 \mathrm{~cm}^{-1}$; ${ }^{1} \mathrm{H}$ NMR and ${ }^{13} \mathrm{C}$ NMR data, see Table 1 ; FABMS $m / z 235\left([\mathrm{M}+\mathrm{H}]^{+}, 0.7\right)$; HRFABMS $m / z 235.1521[\mathrm{M}+\mathrm{H}]^{+}$(calcd for $\left.\mathrm{C}_{15} \mathrm{H}_{23} \mathrm{~S}, 235.1520\right)$.

13. Leriverend, C.; Metzner, P.; Capperucci, A.; Degl'Innocenti, A. Tetrahedron 1997 53, 1323-1342.

14. (2E,6E)-3-Isopropyl-6-methyl-10-oxoundeca-2,6-dienal (3): Primrose yellow oil; $\mathrm{UV}(\mathrm{MeOH}) \lambda_{\max }(\log \varepsilon) 241(3.81) \mathrm{nm} ; \mathrm{IR}(\mathrm{KBr}) v_{\max } 2963,2932,2874,1716$,
1671, 1625, 1463, 1363, $1155 \mathrm{~cm}^{-1}$; ${ }^{1} \mathrm{H}$ NMR and ${ }^{13} \mathrm{C}$ NMR data, see Table 1 ESIMS $m / z 259 \quad[\mathrm{M}+\mathrm{Na}]^{+}$; HRESIMS $\mathrm{m} / z \quad 259.1676 \quad[\mathrm{M}+\mathrm{Na}]^{+}$(calcd for $\mathrm{C}_{15} \mathrm{H}_{24} \mathrm{O}_{2} \mathrm{Na}$, 259.1674).

15. Chabrosterol (4): White amorphous powder; $[\alpha]_{\mathrm{D}}^{25}+28.5\left(\right.$ c $\left.0.1, \mathrm{CHCl}_{3}\right)$; IR $(\mathrm{KBr})$ $v_{\max } 3309,2933,2868,1723,1685,1462,1376,1209 \mathrm{~cm}^{-1} ;{ }^{1} \mathrm{H}$ NMR and ${ }^{13} \mathrm{C}$ NMR data, see Table 2; ESIMS $m / z 421[\mathrm{M}+\mathrm{Na}]^{+}$; HRESIMS $\mathrm{m} / \mathrm{z} 421.3085$ $[\mathrm{M}+\mathrm{Na}]^{+}$(calcd for $\mathrm{C}_{27} \mathrm{H}_{42} \mathrm{O}_{2} \mathrm{Na}, 421.3082$ ).

16. Bortolotto, M.; Braekman, J. C.; Daloze, D.; Losman, D.; Tursch, B. Steroids 1976 28, 461-466.

17. Cheng, S.-Y.; Wen, Z.-H.; Chiou, S.-F.; Wang, S.-K.; Hsu, C.-H.; Dai, C.-F.; Chiang, M. Y.; Duh, C.-Y. Tetrahedron 2008, 64, 9698-9704. 